\title{
Genetisk epidemiologiske studier av psykiatriske lidelser
}

\author{
Ted Reichborn-Kjennerud \\ Divisjon for Epidemiologi, Nasjonalt Folkehelseinstitutt \\ Psykiatrisk Institutt, Universitetet i Oslo \\ Korrespondanse: Nasjonalt Folkehelseinstitutt, Divisjon for Epidemiologi, Postboks 4404 Nydalen, N-0403 Oslo \\ e-post: ted.reichborn-kjennerud@folkehelsa.no
}

\begin{abstract}
SAMMENDRAG
Artikkelen gir en oversikt over genetisk epidemiologiske studier i psykiatrien. Hovedvekten er lagt på familie- og tvillingstudier av angstlidelser, alvorlig depresjon og spiseforstyrrelser. Genetisk epidemiologiske metoder omtales kort. For de fleste ikke-psykotiske psykiatriske lidelser, inkludert rusmiddelmisbruk og -avhengighet, finner man en heritabilitet på mellom 30\% og 80\%. En del av disse estimatene kan være for lave på grunn av manglende diagnostisk reliabilitet. Med få unntak ser det ikke ut til at felles familiemiljø spiller noen signifikant rolle for utviklingen av psykiske lidelser. Kvantitative metoder som tvillingstudier vil fortsatt ha en fremtredende plass i psykiatrisk genetisk epidemiologi på tross av den store ekspansjonen som har funnet sted på det molekylærgenetiske området.
\end{abstract}

\section{Reichborn-Kjennerud T. Genetic epidemiology of psychiatric disorders. Nor J Epidemiol 2002; 12 (2): 145-150.}

\section{ENGLISH SUMMARY}

The article gives an overview of genetic epidemiological studies in psychiatry. The main emphasis is on family- and twin studies of anxiety disorders, major depression and eating disorders. Genetic epidemiological methods are briefly described. For most non-psychotic disorders, the heritability lies between $35 \%$ and $80 \%$. Some of these estimates are probably too low because of imperfect diagnostic reliability. Common family environment does not appear to play a significant role in the development of most psychiatric disorders. Quantitative methods, like twin studies, will remain an important tool for psychiatric genetic epidemiology despite the rapid expansion of molecular genetics.

\section{INNLEDNING}

Det har lenge vært kjent at genetiske forhold er av betydning for utviklingen av schizofreni og maniskdepressiv lidelse, og en rekke forskningsgrupper arbeider nå med å forsøke å identifisere spesifikke gener for disse sykdommene gjennom koblingsstudier og assosiasjonsstudier $(1,2)$. Tvillingstudier av schizofreni har vært utført siden 1930-årene, og estimatene for heritabilitet (andelen av individuelle forskjeller i risiko i en populasjon på et gitt tidspunkt som forklares av genetiske faktorer) er gjennomgående svært konsistente. I de nyeste undersøkelsene (gjort etter 1995) ligger heritabiliteten på mellom $80 \%$ og $85 \%$ (3). Genetiske og miljømessige årsaksforhold for andre psykiatriske lidelser har, inntil for noen år siden, blitt viet mindre oppmerksomhet. Det foreligger i dag studier som indikerer at genetiske risikofaktorer er av betydning for de fleste psykiske lidelser $(4,5)$, inkludert misbruk og avhengighet av alkohol og andre rusmidler $(6,7)$. Denne artikkelen vil kort omtale genetisk epidemiologiske metoder brukt i psykiatrisk forskning og gi en oversikt over familie- og tvillingstudier av angstlidelser, depresjon og spiseforstyrrelser.

\section{GENETISK EPIDEMIOLOGISKE METODER}

I genetisk epidemiologi er familiestudier det første skrittet på veien til å kartlegge om en lidelse er arvelig betinget. Slike studier kan bare si oss om en lidelse forekommer hyppigere i enkelte familier enn i andre, ikke om dette har genetiske årsaker eller skyldes spesielle familieforhold. For å finne ut om genetiske faktorer påvirker sårbarheten for en lidelse kan man bruke adopsjons- eller tvillingstudier. Adopsjonsstudier er i prinsippet en utmerket metode for å studere betydningen av genetiske og miljømessige risikofaktorer, men er av praktiske grunner vanskelig å gjennomføre, og brukes derfor nå relativt lite i psykiatrien. Tvillingstudier har derimot en fremtredende plass innenfor psykiatrisk genetisk epidemiologi $(5,8)$. I løpet av de siste 10-20 år har metodologiske fremskritt, spesielt bruk av strukturelle ligningsmodeller på populasjonsbaserte utvalg (9), utvidet mulighetene som ligger i 
denne type undersøkelser (8). I motsetning til tidligere, hvor man var henvist til å sammenlikne konkordans (samtidig forekomst av en lidelse hos begge tvillinger $i$ et par) mellom eneggede (MZ) og toeggede (DZ) tvillinger, kan man i dag kvantifisere det relative bidraget til variansen $\mathrm{i}$ en lidelse som kommer fra henholdsvis additive genetiske faktorer (A), non-additive genetiske faktorer (D), miljøfaktorer som er felles for tvillingene (C) eller miljøfaktorer som er spesifikke for hvert individ (E). Man er også i stand til å studere kjønnsforskjeller, samspillet mellom genetiske og miljømessige risikofaktorer (korrelasjon og interaksjon) og forandringer i genetiske og miljømessige risikofaktorer over tid (longitudinelle modeller). Tvilling- og adopsjonsstudier kan kombineres, men er svært vanskelig å få til da man er avhengig av å finne frem til et tilstrekkelig antall tvillinger som er adoptert bort til ulike foreldre.

En av de grunnleggende forutsetningene i disse såkalte biometriske tvillingmodellene er at sårbarhet eller risiko for en lidelse er kontinuerlig distribuert (og normalfordelt) i befolkningen. Psykiatriske diagnoser er oftest kategorielt definert, og antas å komme til uttrykk hos individer hvor sårbarheten overstiger en bestemt terskel. Praktisk talt alle psykiatriske lidelser er multifaktorielle, dvs. at en rekke gener i mer eller mindre komplekst samspill med miljøfaktorer bidrar til risikoen. Enkeltgener som er assosiert med en lidelse kan ha ulik effekt, og kalles ofte quantitative trait loci (QTL). Samspillet mellom de ulike genene kan være additativt (effekten av de enkelte gener kan summeres) eller mer komplisert (dominans, epistasis). Bare ved sjeldne tilstander, som f.eks. Huntingtons sykdom, vil et enkelt gen eller en mutasjon føre til sykdom, uavhengig av miljøfaktorer.

Molekylærgenetiske metoder som koblingsstudier og assosiasjonsstudier brukes dersom man ønsker å identifisere spesifikke gener eller QTL $(4,10,11)$. Strukturelle ligningsmodeller gjør det mulig å inkorporere QTL-data i tvillingmodeller, og derigjennom få et kvantitativt uttrykk for hvor mye av variansen i en fenotype som forklares av det spesifikke genet relativt til den totale genetiske variansen.

\section{AngSTLIDELSER}

Ved en rekke psykiatriske lidelser forekommer angst eller irrasjonell frykt som symptom. Moderne klassifikasjonssystemer skiller imidlertid ut enkelte diagnostiske kategorier som "rene" angstlidelser: Enkel fobi, agorafobi, sosial fobi, panikklidelse, generalisert angstlidelse, obsessiv-kompulsiv lidelse og posttramatisk stresslidelse. Befolkningsundersøkelser viser at angstlidelser er den vanligste formen for psykiske lidelser (12). I en nylig publisert norsk studie fra Oslo (13) ble det funnet følgende livstidsprevalenser for de enkelte lidelser: Enkel fobi 14,4\%, sosial fobi 13,7\%, agorafobi $6,1 \%$, panikklidelse $4,5 \%$, generaliser angstlidelse $4,5 \%$ og obsessiv-kompulsiv lidelse $1,6 \%$. Dette er i stor grad i overensstemmelse med resultater fra
USA (12). Forekomsten er gjennomgående 2-3 ganger høyere hos kvinner enn hos menn. Flere angstlidelser forekommer ofte hos samme person (komorbiditet), og det er også økt forekomst av angstlidelser hos personer med depresjon og alkoholisme. Nyere studier peker $i$ retning av at angstlidelser i tidlig alder kan føre til senere økt forekomst av depresjon (14).

\section{Panikklidelse}

Panikklidelse forekommer i løpet av livet hos 6,0\% av kvinner og 2,5\% av menn i Norge. Resultatet av familiestudier peker entydig i retning av at panikklidelse er arvelig, dvs. forekommer hyppigere hos slektninger av probander med panikklidelse sammenliknet med slektninger av normale kontrollpersoner. Beregninger av sykdomsrisikoen hos førstegradsslektningene av probander med panikklidelse varierer fra ca. $8 \%-17 \%$ mens førstegradsslektninger til normale kontroller har $1 \%-4 \%$ risiko for å få panikklidelse (15-18).

Tidlige tvillingstudier, inkludert to fra Norge (19, 20 ), viser en klar arvelighet $i$ form av høyere konkordans mellom MZ tvillinger sammenliknet med DZ tvillinger. Foreløpig foreligger tre studier hvor genetiske og miljømessige effektene er kvantifisert (21-23). Resultatene viser en heritabilitet på mellom $33 \%$ og $43 \%$. Resten av variansen ble forklart av individspesifikke miljøfaktorer. Dette innebærer at det ikke ble funnet indikasjoner på at det felles familiemiljøet var av betydning for utvikling av panikklidelse. Det er ikke funnet kjønnsforskjeller i genetiske og miljømessige effekter på panikklidelse, men man kan ikke utelukke at slike finnes da det kreves svært store utvalg for å få tilstrekkelig statistiske styrke til å kunne konkludere med rimelig grad av sannsynlighet (24).

\section{Generalisert angstlidelse (GAD)}

Familiær opphopning finner man også for GAD. Familiestudier viser en odds ratio for GAD hos førstegangsslektninger av probander med GAD sammenliknet med førstegradsslektninger av normale probander på mellom 5 og 6,6, med en sykdomsrisiko i den første gruppen på fra ca. 9 til 20 i motsetning til 2-3,5 hos førstegradsslektninger fra kontrollgruppen $(15,25)$.

Tvillingstudier viser en heritabilitet på i overkant av $30 \%$ for både kvinner og menn, og at samme gener predisponerer for GAD hos begge kjønn. Hos menn finner man ingen effekt av felles familiemiljø, mens hos kvinner forklarer dette noe over $10 \%$ av variansen. Resten forklares av individspesifikke miljøfaktorer (26,27).

GAD forekommer ofte sammen med alvorlig depresjon. Tvillingstudier hos kvinner indikerer at de samme genene predisponerer for begge lidelser, men at $\mathrm{u}-$ like miljømessig risikofaktorer gjør seg gjeldende (28).

\section{Fobier}

Familiestudier av enkle fobier, agorafobi og sosial fobi viser alle en økt risiko for tilsvarende lidelse hos før- 
stegradsslektninger av probander sammenliknet med førstegradsslektninger av normale kontroller (odds ratio ca. 4). Tvillingstudier viser at den familiære opphopningen $\mathrm{i}$ hovedsak skyldes additive genetiske effekter som forklarer mellom $20 \%$ og $40 \%$ av variansen (29).

\section{Obsessiv-kompulsiv lidelse (OCD)}

OCD forekommer sjeldnere enn andre angstlidelser og det foreligger færre genetisk epidemiologiske studier av denne lidelsen. Familiestudier viser blandede resultater, men $i$ en nylig publisert meta-analyse (29) konkluderes det med at det foreligger økt sykdomsrisiko hos førstegradsslektninger av probander sammenliknet med førstegradsslektninger til kontrollpersoner $(8,2 \%$ vs. 2,0\%). Foreløpig foreligger ingen tvillingstudier på $\mathrm{OCD}$, sannsynligvis på grunn av lav prevalens.

\section{ALVORLIG DEPRESJON}

Livstidsprevalensen for alvorlig depresjon er anslått til å være $17,8 \%$ i Oslo (13). Tilsvarende tall $(17,1 \%)$ er funnet $i$ en landsomfattende studie i USA (12). Forekomsten er dobbelt så høy hos kvinner som hos menn (henholdsvis $24,0 \%$ og 9,9\% i den norske undersøkelsen). Alvorlig depresjon antas å bli den nest viktigste årsak til uførhet på verdensbasis etter ischemisk hjertesykdom i løpet av år 2020 (30).

I løpet av de siste 20 år er det gjort flere store familiestudier (31-35) som alle viser at alvorlig depresjon forekommer hyppigere hos førstegradsslektninger til probander som har denne lidelsen sammenliknet med tilsvarende slektninger av kontrollpersoner (odds ratio ca. 2-4).

Det er gjort en rekke tvillingstudier på alvorlig depresjon. En nylig publisert meta-analyse av de seks metodologisk sett beste undersøkelsene inkluderte 21000 individer, alle diagnostisert $\mathrm{i}$ henhold til internasjonalt anerkjente kriterier (36). Resultatene viste at den familiære opphopningen av alvorlig depresjon kunne tilskrives additive genetiske faktorer som forklarte $37 \%$ av variansen $(95 \% \mathrm{CI}=31 \%-42 \%)$. Felles familiemiljø hadde bare en marginal innflytelse $(95 \%$ $\mathrm{CI}=0 \%-5 \%$ ) mens individspesifikke miljøfaktorer (inkludert målefeil) forklarte de resterende $67 \%$ av variansen. Reliabiliteten for livstidsdiagnosen alvorlig depresjon er moderat. I en longitudinell studie ble den estimert til å være 66\% (37). Dette tilsier at heritabiliteten i realiteten er vesentlig høyere enn $37 \%$ da den manglende reliabiliteten vil føre til en relativ overestimering av individspesifikke miljøfaktorer. Gen-miljø interaksjon kan være av betydning for utviklingen av alvorlig depresjon. For eksempel kan det være at den genetiske sårbarheten for depresjon bare kommer til uttrykk dersom personen utsettes for en eller flere stressende livshendelser, noe som i seg selv kan være influert av genetiske faktorer (38). Tvillingstudier har lav statistisk styrke for å påvise gen-miljø interaksjoner, og tilstedeværelse av slike vil føre til en underestimering av de genetiske effektene. Lav statistisk styrke gjør det også vanskelig å påvise kjønnsforskjeller $\mathrm{i}$ arvelighet selv med relativt store utvalg (24). Nylig publiserte tvillingstudier peker imidlertid i retning av at det kan være ulik størrelse på de genetiske effektene for menn og kvinner, og at en del genetiske risikofaktorer ikke er identiske for begge kjønn $(39,40)$.

\section{SPISEFORSTYRRELSER}

Spiseforstyrrelser som bulimia nervosa og anorexia nervosa forekommer relativt sett sjeldnere enn angstlidelser og depresjon, og kjønnsforskjellene er vesentlig mer uttalt. I den tidligere omtalte epidemiologiske studien fra Norge var livstidsprevalensen for bulimia nervosa $(\mathrm{BN})$ og anorexia nervosa $(\mathrm{AN})$ samlet 3\% hos kvinner og 0,2\% hos menn (13). Det kan se ut som om spiseforstyrrelser forekommer hyppigere i yngre kohorter $(41,42)$. Familiestudier viser at det foreligger familiær opphopning av både anorexia nervosa og bulimia nervosa (43). I den hittil største familiestudien av spiseforstyrrelser ble det i tillegg funnet at slektninger av pasienter med AN har økt forekomst av BN og at slektninger av pasienter med $\mathrm{BN}$ har økt forekomst av AN. Dette indikerer at det foreligger felles sårbarhetsfaktorer for begge lidelser (44). Hvorvidt disse er av genetisk art vites ikke.

På grunn av den lave prevalensen for AN og BN (henholdsvis ca. $0,75 \%$ og $2,5 \%$ hos kvinner, vesentlig lavere for menn), har det vært vanskelig å gjennomføre tvillingstudier med adekvat statistisk styrke (45). Spesielt når det gjelder anorexia nervosa har dette vært et problem. Prevalensen, og dermed den statistiske styrken, kan økes gjennom å bruke noe utvidede diagnostiske kriterier. Det har vært vist at et bredere definert AN syndrom ligger på samme sårbarhetskontinuum som den restriktivt definerte AN lidelsen (46). Ved bruk av denne fremgangsmåten ble det funnet en heritabilitet for anorexia nervosa på 74\%. Resten av variansen ble forklart av individuelle miljøfaktorer (47). En annen måte å øke den statistiske styrke på er å bruke en bivariat modell med en komorbid lidelse som har høyere prevalens. I en slik studie hvor alvorlig depresjon og bredt definert AN ble brukt som fenotyper, ble det funnet en heritabilitet for $\mathrm{AN}$ på 58\% (48). Kovariansen mellom de to lidelsene ble forklart av felles genetisk sårbarhet (korrelasjon mellom genetiske sårbarhetsfaktorer: 0,34). Det var ingen signifikant korrelasjon mellom de miljømessige risikofaktorene. Bruk av gjentatte målinger er en tredje måte å øke statistisk styrke på. Det foreligger to studier med bruk av denne fremgangsmåten for bredt definert $\mathrm{BN}$, hvor heritabiliteten ble estimert til å være henholdsvis 83\% (49) og $59 \%$ (50). I den første studien ble det korrigert for lav diagnostisk reliabilitet $(\kappa=0,28)$ gjennom bruk av diagnostisk informasjon på to ulike tidspunkt. Felles familiemiljø hadde ingen signifikant effekt. Undersøkelser på delsymptomer ved $\mathrm{BN}$ viser en heritabilitet for overspising ("binge-eating") på $46 \%$ og for selvindusert oppkast på $72 \%$ (50). 


\section{KONKLUSJON - FREMTIDIG FORSKNING}

Kvantitative genetiske studier har vist at genetiske sårbarhetsfaktorer spiller en fremtredende rolle også for ikke-psykotiske psykiatriske lidelser. Heritabiliteten varierer fra ca. $35 \%$ til $80 \%$. En del av disse estimatene antas å være for lave på grunn av manglende diagnostisk reliabilitet. Felles familiemiljø ser ikke ut til å spille noen signifikant rolle for utviklingen av de fleste psykiske lidelser. En rekke molekylærgenetiske studier er utført eller iverksatt for å forsøke å identifisere spesifikke gener, uten at man foreløpig har lykkes. Optimismen er imidlertid fremdeles meget stor. Kvantitative metoder som tvillingstudier vil likevel ha sin plass i den psykiatriske genetiske epidemiologien. Fordi psykiske lidelser er multifaktorielle, er årsaksforholdene sannsynligvis svært komplekse, og vil som regel involvere mange gener og mange miljøfaktorer med interaksjoner på flere nivåer. Tvillingstudier vil være et nyttig hjelpemiddel for å avklare interaksjoner mellom spesifikke gener (QTL) og uidentifiserte genetiske faktorer, mellom ulike miljøfaktorer, og mellom genetiske og miljømessige faktorer. De vil også kunne benyttes til å etablere mer raffinerte fenotyper for molekylærgenetiske studier og til å identifisere endofenotyper eller markører for genetisk sårbarhet gjennom bruk av data fra f.eks. nevropsykologiske tester eller moderne teknikker for avbildning av hjernen (5). Tvillingstudier vil videre kunne benyttes til å utrede i hvilken grad det eksisterer spesifikke genetiske sårbarhetsfaktorer for de ulike psykiatriske lidelsene eller felles genetisk predisposisjon for flere lidelser som vil kunne komme til utrykk på forskjellige måter avhengig av den miljømessige påvirkning $(39,52)$. Longitudinelle tvillingstudier vil kunne gi informasjon om utviklingsmessige aspekter ved psykiatriske lidelser gjennom å undersøke endringer i genetiske og miljømessige risikofaktorer over tid (53).

\section{REFERANSER}

1. Riley BP, McGuffin P. Linkage and associated studies of schizophrenia. Am J Med Genet 2000; 97: 23-44.

2. Craddock N, Jones I. Molecular genetics of bipolar disorder. Br J Psychiatry 2001; 178 (suppl. 41): 128-133.

3. Cardno AG, Gottesman II. Twin studies of schizophrenia: From bow-and-arrow concordances to star wars $\mathrm{Mx}$ and functional genomics. Am J Med Genet 2000; 97: 12-17.

4. Plomin R, DeFries JC, McClearn GE, McGuffin P. Behavioral Genetics. New York: Worth Publishers, 2001: 204-258.

5. Kendler KS. Twin studies of psychiatric illness. An update. Arch Gen Psychiatry 2001; 58: 1005-1014.

6. Schuckit MA. Genetics of the risk for alcoholism. Am J Addict 2000; 9: 103-112.

7. Tsuang MT, Bar JL, Harley RM, Lyons MJ. The Harvard Twin Study of Substance Abuse: what we have learned. Harv Rev Psychiatry 2001; 9: 267-279.

8. Kendler KS. Twin studies of psychiatric illness: current status and future directions. Arch Gen Psychiatry 1993; 50: 905-915.

9. Neal MC, Cardon LR. Methodology for genetic studies of twins and families. Dortrecht: Kluwer Academic, 1992.

10. Sullivan PF, Eaves LJ, Kendler KS, Neale MC. Genetic case-control association studies in neuropsychiatry. Arch Gen Psychiatry 2001; 58: 1015-1024.

11. Sham P. Statistics in human genetics. London: Arnold, 1998.

12. Kessler RC, McGonagle KA, Zhao S, Nelson CB, Hughes M, Eshleman S, Wittchen H-U, Kendler KS. Lifetime and 12-month prevalence of DSM-III-R psychiatric disorders in the United States: results from the National Comorbidity Survey. Arch Gen Psychiatry 1994; 51: 8-19.

13. Kringlen E, Torgersen S, Cramer V. A Norwegian psychiatric epidemiological study. Am J Psychiatry 2001; 158: 1091-1098.

14. Kessler RC, Stang A, Wittchen H-U, Stein M, Walters EE. Lifetime co-morbidities between social phobia and mood disorders in the US National Comorbidity Survey. Psychol Med 1999; 29: 555-567.

15. Mendelewicz J, Papadimitriou GN, Wilmotte J. Family study of panic disorder: comparison with generalized anxiety disorder, major depression and normal subjects. Psychiatr Genet 1993; 3: 73-78.

16. Maier W, Lichtermann D, Minges J, Oehrlein A, Franke P. A controlled family study in panic disorder. $J$ Psychiat Res 1993; 27 (suppl. 1): 79-87.

17. Horwath E, Wolk SI, Goldstein RB, Wickamaratne P, Sobin C, Adams P, Lish JD, Weissman MM. Is the comorbidity between social phobia and panic disorder due to familial cotransmission or other factors? Arch Gen Psychiatry 1995; 52: 574-582.

18. Fyer AJ, Mannuzza S, Chapman TF, Lipsitz J, Martin LY, Klein DF. Panic disorder and social phobia: effects of comorbidity on familial transmission. Anxiety 1996; 2: 173-178.

19. Torgersen S. Genetic factors in anxiety disorders. Arch Gen Psychiatry 1983; 49: 1085-1089. 
20. Skre I, Onstad S, Torgersen S, Lygren S, Kringlen E. A twin study of DSM-III-R anxiety disorders. Acta Psychiatr Scand 1993; 88: 85-92.

21. Kendler KS, Neale MC, Kessler RC, Heath AC, Eaves LJ. Panic disorder in women: a population-based twin study. Psychol Med 1993; 23: 397-406.

22. Scherrer JF, True WR, Xian H, Lyons M, Eisen SA, Goldberg J, Lin N, Tsuang MT. Evidence for genetic influences common and specific to symptoms of generalized anxiety and panic. J Affect Disord 2000; 57: 2535 .

23. Kendler KS, Gardner CO, Prescott CA. Panic syndromes in a population-based sample of male and female twins. Psychol Med 2001; 31: 989-1000.

24. Neale MC, Eaves LJ, Kendler KS. The power of the classical twin study to resolve variation in threshold traits. Behav Gen 1994; 24: 239-258.

25. Noyes R, Clarkson C, Crowe RR, Yates WR, McChesney CM. A family study of generalized anxiety disorder. Am J Psychiatry 1987; 144: 1019-1024.

26. Hettema JM, Prescott CA, Kendler KS. A population-based twin study of generalized anxiety disorder in men and women. J Nerv Ment Dis 2001; 189: 413-420.

27. Kendler KS, Neale MC, Kessler RC, Heath AC, Eaves LJ. Generalized anxiety disorder in women. A population-based twin study. Arch Gen Psychiatry 1992; 49: 267-272.

28. Kendler KS, Neale MC, Kessler RC, Heath AC, Eaves LJ. Major depression and generalized anxiety disorder. Same genes, (partly) different environments? Arch Gen Psychiatry 1992; 49: 716-722.

29. Hettema JM, Neale MC, Kendler KS. A review and meta-analysis of the genetic epidemiology of anxiety disorders. Am J Psychiatry 2001; 158: 1568-1578.

30. Murray CJL, Lopez AD. Evidence-based health policy: lessons from the Global Burden of Disease Study. Science 1996; 274: 740-743.

31. Gershon ES, Hamovit J, Guroff JJ, Dibble E, Leckman JF, Sceery W, Targum SD, Nurnberger JI, Goldin LR, Bunney WE. A family study of schizoaffective, bipolar I, bipolar II, unipolar and normal control probands. Arch Gen Psychiatry 1982; 39: 1157-1167.

32. Maier W, Lichtermann D, Minges J, Hallmayer J, Heun R, Benkert O, Levinson DF. Continuity and discontinuity of affective disorders and schizophrenia: results of a controlled family study. Arch Gen Psychiatry 1993; 50: $871-883$.

33. Tsuang MT, Winokur G, Crowe RR. Morbidity risks of schizophrenia and affective disorders among first degree relatives of patients with schizophrenia, mania, depression and surgical conditions. Br J Psychiatry 1980; 137: 497-504.

34. Weissman MM, Gershon ES, Kidd KK, Prusoff BA, Leckman JF, Dibble E, et al. Psychiatric disorders in the relatives of probands with affective disorders. The Yale University-National Institute of Mental Health Collaborative Study. Arch Gen Psychiatry 1984; 41: 13-21.

35. Weissman MM, Wickramaratne P, Adams PB, Lish JD, Horwath E, Charney D, et al. The relationship between panic disorder and major depression. A new family study. Arch Gen Psychiatry 1993; 50: 767-780.

36. Sullivan PF, Neale MC, Kendler KS. Genetic epidemiology of major depression: review and meta-analysis. Am J Psychiatry 2000; 157: 1552-1562.

37. Foley DL, Neale MC, Kendler KS. Reliability of a lifetime history of major depression: implications for heritability and co-morbidity. Psychol Med 1998; 28: 857-870.

38. Kendler KS, Kessler RC, Walters EE, MacLean C, Neale MC, Heath AC, et al. Stressful life events, genetic liability, and onset of an episode of major depression in women. Am J Psychiatry 1995; 152: 833-842.

39. Kendler KS, Prescott CA. A population-based twin study of lifetime major depression in men and women. Arch Gen Psychiatry 1999; 56: 39-44.

40. Kendler KS, Gardner CO, Neale MC, Prescott CA. Genetic risk factors for major depression in men and women: similar or different heritabilities and same or partly distinct genes? Psychol Med 2001; 31: 605-616.

41. Gotestam KG, Agras WS. General population-based study of eating disorders in Norway. Int J Eating Disord 1995; 18: 119-126.

42. Kendler KS, MacLean C, Neale M, Kessler R, Heath A, Eaves L. The genetic epidemiology of bulimia nervosa. Am J Psychiatry 1991; 148: 1627-1637.

43. Strober M, Bulik CM. Genetic epidemiology of eating disorders. In: Fairburn CJ, Brownell KD, eds. Eating Disorders and Obesity. A Comprehensive Handbook. London: Guilford Press, 2002.

44. Strober M, Freeman R, Lampert C, Diamond C, Kaye W. Controlled family study of anorexia nervosa and bulimia nervosa: evidence of shared liability and transmission of partial phenotypes. Am J Psychiatry 2000; 157: 393-419.

45. Bulik CM, Sullivan PF, Wade TD, Kendler KS. Twin studies of eating disorders: a review. Int J Eat Disord 2000; 27: 1-20. 
46. Walters EE, Kendler KS. Anorexia nervosa and anorexic-like syndromes in a population-based female twin sample. Am J Psychiatry 1995; 152: 64-71.

47. Klump KL, Miller KB, Keel PK, McGue M, Iacono WG. Genetic and environmental influences on anorexia nervosa syndromes in a population-based twin sample. Psychol Med 2001; 31: 737-740.

48. Wade TD, Bulik CM, Neale M, Kendler KS. Anorexia nervosa and major depression: shared genetic and environmental risk factors. Am J Psychiatry 2000; 157: 469-471.

49. Bulik CM, Sullivan PF, Kendler KS. Heritability of binge-eating and broadly defined bulimia nervosa. Biol Psychiatry 1998; 44: 1210-1218.

50. Wade T, Neale MC, Lake RI, Martin NG. A genetic analysis of the eating and attitudes associated with bulimia nervosa: dealing with the problem of ascertainment in twin studies. Behav Genet 1999; 29: 1-10.

51. Sullivan PF, Bulik CM, Kendler KS. Genetic epidemiology of binging and vomiting. Br J Psychiatry 1998; 173: 75-79.

52. Kendler KS, Walters EE, Neale MC, Kessler RC, Heath AC, Eaves LJ. The structure of the genetic and environmental risk factors for six major psychiatric disorders in women. Phobia, generalized anxiety disorder, panic disorder, bulimia, major depression, and alcoholism. Arch Gen Psychiatry 1995; 52: 374-383.

53. Eaves LJ, Long J, Heath AC. A theory of developmental change in quantitative phenotypes applied to cognitive development. Behav Genet 1986; 16: 143-162. 